\title{
The effect of temperature on the okra drying process: kinetic study and physical properties of powders
}

\section{Francislaine Suelia dos Santos*, Rossana Maria Feitosa de Figueirêdo, Alexandre José de Melo Queiroz, Ana Raquel Carmo de Lima and Thalis Leandro Bezerra de Lima}

\author{
Department of Agricultural Engineering, Federal University of Campina Grande (UFCG), Aprígio Veloso Street, 882, \\ Campina Grande, Brazil, CEP - 58429-970
}

\section{*Corresponding author: francislainesuelis@gmail.com}

\begin{abstract}
This study aimed to evaluate the effect of drying temperature $\left(50,60,70\right.$ and $\left.80^{\circ} \mathrm{C}\right)$ on okra dehydration by comparing its powder's physical properties obtained from a sample produced by a lyophilization process. Ten drying models were adjusted to the experimental data of the drying kinetics. As a result, effective diffusivity and activation energy were determined in addition to thermodynamic parameters: entropy, enthalpy and Gibbs free energy. A physical characterization, as well as the pigments and colorimetry analyses of the aforementioned powders were made, by comparing them with samples produced by lyophilization. The powders were characterized for hygroscopicity, solubility, wettability, apparent and compacted density, fluidity and cohesiveness, pigments, colorimetric, morphological analysis (SEM) and X-ray diffraction. Midilli model was the one that best adjusted to the drying kinetic curves. There was a booster in the effective diffusion coefficient with the increase of temperature. Enthalpy and entropy were reduced with the increase of both drying temperature and Gibbs free energy. The powders presented high luminosity, and the lyophilized powder had higher pigments retention and greater solubility. All powders presented poor fluidity and intermediate cohesiveness, with amorphous, irregular and asymmetric particles. Thus, from the present study it was possible to evaluate the best drying method, the one that should be applied for the drying of okra, considering the costs involved, its quality and the final application of the product, meeting the specific needs of each consumer.
\end{abstract}

Keywords: Abelmoschus esculentus (L.) Moench; convective drying; lyophilization; physicochemical analyses; thermodynamic properties.

Abbreviations: -a*_green intensity; +b*_yellow intensity; $C^{*}$ _chroma; Cl_carr index; a, b, c, k, K1, n_drying constants; Def_effective diffusivity; DQM_mean squared deviations; $F H \_h a u s n e r$ factor; $L^{*}$ _luminosity; $R^{2}$ _ coefficients of determination; SEM_morphological analysis; T_temperature; $\Delta H_{-}$enthalpy; $\Delta \mathrm{S}$ _entropy; $\Delta \mathrm{G} \_$Gibbs free energy.

\section{Introduction}

Okra (Abelmoschus esculentus (L.) Moench) is a malvaceae that comes from Africa, has commercial importance and expansion of cultivation in almost all tropical and subtropical areas, standing out for presenting a fast vegetative cycle, of high yield, with low costs of production and high nutritional value (Nascimento et al., 2013; Roy et al., 2014).

It is a fibrous vegetable, similar to a long pod, rich in fiber, proteins, vitamins $\mathrm{A}$ and $\mathrm{C}$, calcium, iron, and niacin. Besides having medicinal properties, the seeds are also a good source of oil, proteins, fats, fiber, and sugars (Fan et al., 2014; Mota et al., 2010). It is a rich source of mucilage, presenting considerable pectin and lignin content (Kpodo et al., 2017).

This vegetable is harvested and consumed when partially developed and physiologically immature, they present high perishability, with conservation limited to a short period of time, due to its respiratory metabolism that remains active, with chemical transformations that occur until it reaches or surpasses the maturation stage, resulting in commercial value loss and disinterest by the consumers.

Dehydration is one of the most important procedures used in the processing of agricultural products since it increases its shelf-life and preserves considerably the nutritional properties with no need for refrigeration. Due to the great diversity of drying techniques available, the choice of the method to be used should consider mainly the relationship between both the costs involved and the desired final quality, in which the methods of convective drying and lyophilization are placed at extremes.

Convective drying has noticeable advantages due to its low complexity and simplicity of equipment, with functionalities mainly directed to temperature control. When properly applied, it can produce good quality products at relatively low 
cost. Regarding thermosensitive nutrients, it can result in losses, mainly of volatiles, which is its main disadvantage.

In regard to the lyophilization process, previously frozen samples had the moisture content reduced by sublimation and then by desorption (Geidobler et al., 2013), resulting in both advantages and disadvantages, inverse to those observed in the convective drying process. It has high costs, is a timeconsuming process with high energy expenditure, and it originates products with maximum principles and nutrients retention of raw material in natura.

It is important to highlight that there is a growing demand not only from consumers, but also from the food industry, that aims at having the maximum diversity of vegetables in nonperishable lines, conveniently prepared to maintain the main characteristics of the raw material in natura and ready for use. Therefore, the present study aims to evaluate the effect of drying temperature on okra dehydration at different temperatures and to compare their powders physical and colorimetric properties with lyophilized samples. In order to evaluate the best method to be used for dehydrating okra, it was necessary to take into account the relationship between its costs and their desired final quality, according to consumers' needs.

\section{Results and discussion}

\section{Drying kinetics}

In Table 1 are presented the following mathematical models: Parameters of diffusion approximation, Two terms, Exponential of two terms, Henderson and Pabis, Logarithmic, Midilli, Newton, Page and Thompson and Wang and Singh; that were adjusted to the drying data of dehydrated okra at 50,60, 70 and $80^{\circ} \mathrm{C}$, showing the coefficients of determination and the mean squared deviations.

All models had good adjustments, with coefficients of determination higher than 0.98 and mean squared deviations lower than 0.06, especially the Midilli model with the highest $R^{2}$ (> 0.9999) and the lowest DQM $(<0.013)$, at all drying temperatures. Silva et al. (2017) dried carrots in forced air circulation at 50,60, 70 and $80{ }^{\circ} \mathrm{C}$, adjusted mathematical models to the experimental data and obtained the best adjustment with the Midilli model. Derlan et al. (2013) when evaluated the drying kinetics of Cambuci pepper (Capsicum baccatum L. var. Pendulum) in a forced circulation oven at 40 , 50 and $60^{\circ} \mathrm{C}$ also obtained the best adjustments with the same model.

The drying constant $k$ of the tested models showed an increasing tendency with the increase of temperature, as a consequence of higher drying rates, as suggested by Corrêa et al. (2010), who related parameter $k$ to drying rates, leading to the equilibrium of moisture content in a shorter product exposure time to the drying air. An increase of constant $k$, after increasing the drying temperature, was reported by many authors, such as Nascimento et al. (2015) when studying algaroba pods (Prosopis juliflora SW) dried at 60,70 and $80^{\circ} \mathrm{C}$; by Moscon et al. (2017) in quinoa grains (Chenopodium quinoa W.) dried at $40,50,60$ and $70{ }^{\circ} \mathrm{C}$; and by Santos et al. (2019) when evaluating the mathematical modeling of acuri slices (Attalea phalerata Mart.) at $60,70,80$ and $90^{\circ} \mathrm{C}$.

The constant $n$ from Midilli and Page models, that are related to the internal resistance of the material to the drying (Perez et al., 2013), did not present a defined behavior with temperature increases, which suggests that the external conditions present a greater influence on the drying process. Martins et al. (2014) verified the same, when adjusting the Midilli model to the bark kinetic of mulungu (Erythrina velutina) at $40,50,60$ and $70{ }^{\circ} \mathrm{C}$, which showed no dependence of the parameter $n$ with the temperature increase.

Figure 1 shows the drying kinetics curves adjusted by the Midilli model, chosen to represent the curves due to the best set of $R^{2}$ and DQM values. It was observed an influence of temperature on the curves, in which a consistent decrease was shown in the drying time due to the increase of temperature. A similar behavior was reported by both Corrêa Filho et al. (2015), when drying fig (Ficus carica L.) at 40,55 and $70{ }^{\circ} \mathrm{C}$, and Elmas et al. (2019) in the drying of jujuba (Zizyphus jujuba) in convective drying at 60,70 and $80^{\circ} \mathrm{C}$.

The okra drying times were 650, 540, 450 and 345 minutes at the temperatures of $50,60,70$ and $80{ }^{\circ} \mathrm{C}$ respectively, presenting final moisture contents of $6.99 \%$ hb at $50{ }^{\circ} \mathrm{C}, 65 \%$ at $60{ }^{\circ} \mathrm{C}, 5.28 \%$ at $70^{\circ} \mathrm{C}$ and $1.69 \%$ at $80^{\circ} \mathrm{C}$. As already verified, the drying curves were influenced by the temperature, a gradual decrease in time dehydration was observed as the airdrying temperature increased. Ratifying the high values of $R^{2}$ and low values of DQM for the selected model, it was verified that the experimental points remained very close to the prediction curves.

Several studies related to the drying of vegetable products obtained a better description of the drying phenomena after using the Midilli model. For instance, Melo et al. (2015) in the drying of chilli pepper (Capsicum chinense), in an oven without air circulation at 50, 60 and $70{ }^{\circ} \mathrm{C}$; and Doymaz and Medine (2016) in the drying of broccoli slices, with and without treatments (bleaching and citric acid), in convective drying at $45,55,65$ and $75{ }^{\circ} \mathrm{C}$, being thus the Midilli model the one that adequately described their drying characteristics.

\section{Effective diffusivity}

In Table 2 both the effective diffusivity coefficients (Def), estimated by the Fick model of okra drying under different temperatures, and the determination coefficients are presented. Increases in diffusivity were observed with the increase in temperature, which represents the velocity at which the water migrates from the interior to the product surface. According to Goneli et al. (2014) the water viscosity reduces with the increase in temperature, favoring its movement and boosting its diffusion in the solid matrix. According to Gupta and Alam (2014), as the temperature is increased the effective diffusivity also increases due to vapor pressure extension inside the sample.

The magnitude of the effective diffusivity coefficients, which vary between $3.13 \times 10^{-11}$ and $9.00 \times 10^{-11} \mathrm{~m}^{2} \mathrm{~s}^{-1}$, are in the range indicated by Madamba (2003), in which values of coefficient diffusivity for food products are between $10^{-11}$ and $10^{-9} \mathrm{~m}^{2} \mathrm{~s}^{-1}$. Leite et al. (2015) determined values of 5.64 to 9.86 $x 10^{-10} \mathrm{~m}^{2} \mathrm{~s}^{-1}$ in sliced and dehydrated bananas of Musa sapientum variety in convective drying at temperatures of 40 $60{ }^{\circ} \mathrm{C}$. The coefficients of determination $\left(R^{2}\right)$ were higher than 
0.950, which means that the Fick model was satisfactorily adjusted to the experimental data.

The activation energy for the liquid diffusion of okra was 32.46 kJ mol-1. Corrêa et al. (2007) described activation energy as being the difficulty with which water molecules face when breaking the energy barrier, during the movement of the product, in a way that the lower the activation energy, the greater the water diffusivity, as corroborated in the present study. Doymaz and Medine (2016), dried sliced broccoli in a convective dryer at $45,55,65$ and $75{ }^{\circ} \mathrm{C}$ and reported activation energy of $35.41 \mathrm{~kJ} \mathrm{~mol}^{-1}$. According to Zogzas et al. (1996) the activation energy values for agricultural products vary from 12.7 to $110 \mathrm{~kJ} \mathrm{~mol}^{-1}$, and this variation is justified, according to Martins et al. (2015) due to the physical and biological characteristics of the products.

\section{Thermodynamic properties}

In Table 3 the enthalpy, entropy, and Gibbs free energy values, obtained in the drying process of okra at temperatures of 50$80{ }^{\circ} \mathrm{C}$, are presented. Enthalpy values were inversely proportional to temperatures. Resende et al. (2018) in the air drying of baru (Dipteryx alata Vogel) at $40,60,80$ and $100{ }^{\circ} \mathrm{C}$ verified the same behavior for this parameter. Goneli et al. (2010) stated that the energy required for removing water from the product, which during the drying process occurs by diffusion, is composed of vaporization enthalpy ratio and free water vaporization enthalpy in the product or isosteric heat. Thus, with the increase in temperature and the respective increase of the partial vapor pressure of the water inside the material, there is a reduction in vaporization enthalpy and, therefore, in the final enthalpy balance. In short, there is a reduction in the enthalpy that comes from the process of the product's water diffusion, during the drying process (Araujo et al., 2017).

Entropy behaved similarly to enthalpy, with decreases following the increase in temperature. Due to the rising in drying air temperature and its consequent increase in the partial pressure of water vapor in the product, there is an increase in the excitation of water molecules and a decrease in viscosity, factors that combined booster the water diffusion speed process and, as a result, causes reduction of entropy in the process (Goneli et al., 2010). According to Moreira et al. (2008), negative entropy values are attributed to the existence of chemical adsorption and/or structural modifications of the adsorbent.

Gibbs free energy is a thermodynamic parameter that quantifies the maximum energy released in a process. It occurs under constant temperature and pressure conditions. This energy can serve as an indicator of an useful work performed, and its positive value is explained by an addition of energy that involves the product to the occurrence of phase change (liquid to vapor), when, in the case of drying, there is no chemical reaction, which identifies this operation as non-spontaneous (Araujo et al., 2017).

Gibbs free energy increased with the expansion of drying temperature, similarly to what was observed for some scholars when studying timbó leaves (Serjania marginata Casar) dried at $40,50,60$ and $70{ }^{\circ} \mathrm{C}$, with values of $140.10 \mathrm{~kJ}$ $\mathrm{mol}^{-1}, 142.07 \mathrm{~kJ} \mathrm{~mol}^{-1}, 144.03 \mathrm{~kJ} \mathrm{~mol}^{-1}$ and $145.99 \mathrm{~J} \mathrm{~mol}^{-1}$, respectively (Martins et al., 2015); when drying sunflower seeds (Helianthus annuus), at 40,60, 80 and $100{ }^{\circ} \mathrm{C}$, with values of $93.52 ; 97.99 ; 102.46$ and $106.95 \mathrm{~kJ} \mathrm{~mol}^{-1}$, respectively (Carvalho et al., 2018); and when slicing strawberries (Fragaria sp. L.) at 40,50 and $60{ }^{\circ} \mathrm{C}$, with Gibbs free energy values of $74.16,76.54$ and $78.93 \mathrm{~kJ} \mathrm{~mol}^{-1}$, respectively (Oliveira et al., 2015).

\section{Powders' physical characterization}

Pigment and colorimetric analysis

The mean values and standard deviations of the pigments and colorimetric parameters of okra powders obtained by lyophilization and convective drying at temperatures of 50 to $80^{\circ} \mathrm{C}$ are shown in Table 4.

Chlorophyll content ( $\mathrm{a}, \mathrm{b}$ and total) were found on a higher concentration in lyophilized powder and differed statistically from the powders obtained in convective drying, in which chlorophyll degradation was observed with the increase in temperature. This degradation is attributed to protein denaturation, which leaves chlorophylls unprotected and subjected to degradation, which is also triggered by $\mathrm{pH}$ and temperature, light and oxygen variations on the sample (Bohn and Walczyk, 2004). The degradation of the chlorophylls with the increase of convective air drying temperature is also instrumentally inferred by the powders colorimetric analysis, in which the luminosity as well as the green and yellow intensities were changed with the increase in drying temperature.

The lyophilization process also preserved powder carotenoids better than the convective drying process, in which a higher value was observed at $50{ }^{\circ} \mathrm{C}$, followed by reduction and there was no statistical difference between the other temperatures, which indicates that carotenoids were not susceptible to degradation rise with the increase in temperature. Moreira et al. (2018) when dehydrated kiwi slices in a greenhouse, with air circulation at $70^{\circ} \mathrm{C}$, reported carotenoid content of $1.11 \mu \mathrm{g}$ $\mathrm{g}^{-1}$.

The luminosity $\left(L^{*}\right)$ was higher in the lyophilized powder, with an increasing tendency in the convective drying temperature, as the dehydration temperature increased. This behavior may be associated with the shorter residence time of the product in the dryer, with consequent lower exposure to degradation at higher temperatures. Ren et al. (2017) when studying the effect of drying methods (lyophilization, hot air drying, drying in a greenhouse and drying in a vacuum oven), in both organic and non-organic onions of Red Baron and Hyfort varieties, found that the lyophilized material had a higher luminosity when compared to those under different drying processes.

The green intensity was reduced in the convective drying with the increase in temperature, inversely to the yellow color (+ $\left.b^{*}\right)$. In both cases, presenting values lower than the lyophilization ones. Guiné et al. (2014) when evaluated the influence of different drying process (lyophilization, air circulating greenhouse and tunnel drier) on peeled cucumber slices, verified higher values of -a * for lyophilized powder. In contrast, in convective drying in greenhouses with air circulation at 40 and $60{ }^{\circ} \mathrm{C}$ an increase in the parameter $\mathrm{b} *$ was observed, when increasing temperature.

Chroma $\left(C^{*}\right)$ was higher in the lyophilized powder, close to that obtained in the convective drying at $80{ }^{\circ} \mathrm{C}$, and progressive decreases were observed with the decrease in the convective drying temperature. According to Canuto et al. 
(2010), in the sensorial equivalence, the lyophilized powder presents a more intense tonality than the powders of the convective drying, which present greater opacity. The powders tended to neutral colors, especially to gray (values closer to zero), since values close to 60 express vivid colors (Mendonça et al., 2003). Approximate chroma values were verified in acerola with seeds flour, dehydrated at 60 and $70{ }^{\circ} \mathrm{C}$, with $\mathrm{C}^{*}$ values of 34.1 and 36.30, respectively (Reis et al., 2017).

The hue angle (h) deviated from the red region, which corresponds to the angle $\mathrm{h}=0^{\circ}$ and approached the yellow region ( $h=90^{\circ}$ ) (Alves et al., 2008). The significant increase of component $h$, from $84.29^{\circ}$ (lyophilized powder) to $87.67^{\circ}$ (convective drying at $80^{\circ} \mathrm{C}$ ), shows a deviation from the standard, represented by the lyophilized sample as the drying temperature increased. Oliveira et al. (2016) verified for baru (Dipteryx alata Vogel), dried in an oven with air circulation at 60 to $100{ }^{\circ} \mathrm{C}$, shade angles that ranged from 60.00 to 62.48 , values that are in the same quadrant of those obtained for the okra.

\section{Physical characterization}

In table 5 the mean values of the powder samples' physical characterization, obtained by both lyophilization and convective drying at 50 to $80{ }^{\circ} \mathrm{C}$, are presented. The powders showed high hygroscopicity, except for the powder obtained by convective drying at $50{ }^{\circ} \mathrm{C}$. All the samples were classified, according to GEA Niro (2003), as extremely hygroscopic (> $25 \%)$. The increase in convective drying temperature promoted a reduction in hygroscopicity, which may be related to the amorphous state of the powders and the amount of amorphous sugar (Jaya and Das, 2004). Santos et al. (2017) when evaluated bark powders of white pitaya (Hylocereus undatus) at 50,60 and $70{ }^{\circ} \mathrm{C}$ observed hygroscopicity values of $22.19,23.45$ and $24.60 \%$, respectively. Moreover, Fernandes et al. (2014) reported for dehydrated tomato pulp at 60 and 80 ${ }^{\circ} \mathrm{C}$, values of 57.88 and $57.50 \%$, respectively.

The wettability rate increased as the drying temperature also increased, which can be attributed to the water content, since the wettability is inversely proportional to it. Lannes and Medeiros (2003) stated that powders with good wettability take up to 5 minutes in order to be $90 \%$ immersed, this is not observed for okra powder, which indicates difficulties of reconstitution in the water, at ambient temperature.

The solubility values were significantly higher in the lyophilized powder and presented an increasing tendency in the convective drying samples between 50 and $80{ }^{\circ} \mathrm{C}$, although with no significant differences. The great difference between the solubility of the lyophilized powder and the powders of the convective drying can be justified by the greater particle aggregation of the convective dried samples. Kuck and Noreña (2016) stated that the lower the water content, the more soluble the product, which was corroborated in the okra powders.

The apparent density inversely followed the drying temperature and reached the lowest value in the lyophilized powder. Apparent density values are related to the water content of the powders. In short, the higher the temperature, the lower the water content and solubility; as well as, the lower the density, the higher the solubility (Sogi et al., 2015). Density value allows the calculation of the required volume in the production chain, from its packaging to spaces in transportation and storage. Souza et al. (2012) found in breadfruit mesocarp, Apyrena variety, dehydrated in a tray dryer at $60{ }^{\circ} \mathrm{C}$, a density of $0.610 \mathrm{~g} \mathrm{~cm}^{3}$. The compacted density followed the tendency observed in the apparent density with a lower value observed in the lyophilized powder and a significant decrease with the increase in temperature. Dehydrated tomato pulp, by convective drying at 60 and $80^{\circ} \mathrm{C}$, resulted in powders with compacted density of 0.267 and $0.454 \mathrm{~g} \mathrm{~cm}^{-3}$, respectively (Fernandes et al., 2014).

Carr index $(\mathrm{Cl})$ showed decreases under convective drying between temperatures of 50 and $80{ }^{\circ} \mathrm{C}$. There were no statistical differences between the lyophilized powder and drying powders at the temperatures of 50,60 and $70^{\circ} \mathrm{C}$. The $\mathrm{Cl}$ corresponds to the fluidity capacity of the powders, in which values between 20-35, as determined, classify them as poor flowability (Santhalakshmy et al., 2015). Goyal et al. (2015) when evaluated the flaxseed oil powder, obtained by spraydrying at $177{ }^{\circ} \mathrm{C}$, with addition of whey protein, concentrate and sodium caseinate, observed $\mathrm{Cl}$ in between 33.82 to $34.57 \%$.

The Hausner factor (FH), which evaluates the cohesiveness of the powders, had the same behavior observed for the Carr Index, regarding drying temperature and lyophilized powder. Okra powders, obtained in both drying methods, are classified as having intermediate cohesiveness, according to Santhalakshmy et al. (2015), who states that powders with FH of less than 1.2 are classified as having low cohesiveness, $\mathrm{FH}$ between 1.2 and 1.4 of intermediate cohesiveness and $\mathrm{FH}>$ 1.4 , high cohesiveness.

\section{Particle morphology}

Figure 2 shows the photomicrographs of the powders obtained by convective drying and lyophilization. Despite the difference in the drying methods and the range of different temperatures used in the convective drying, the microstructures were similar in all powders. It was observed morphologically asymmetrical structures with different sizes and shapes, though. The irregularity in powder particles shape can be attributed to its obtaining process. By grinding the samples in a knife mill, there is a disintegration of the structures of the dry material resulting in fragmentations and asymmetries. Lyophilized powder's porosity, observed in Figure $2 \mathrm{~A}$, can be correlated with more or less loose blades of the material interspersed with voids. According to Harnkarnsujarit et al. (2012) porosity can be influenced by the freezing method used, in which freezing temperatures near $-18^{\circ} \mathrm{C}$ favor the formation of larger pores and thicker walls, while lower freezing temperatures form smaller pores and finer walls. Caparino et al. (2012) performed the dehydration of mango pulp using different drying methods (Refractance Window ${ }^{\circ}$, drum drying, spray drying and lyophilization) and found by analysing the microstructure of the samples, that lyophilization formed powders with a more porous structure, if compared to other drying methods.

On one hand, the variation in the drying temperature did not result in significant differences in the particles size. On the other hand, resulted in the formation of a more compacted structure. It is important to highlight that materials with compacted surfaces contribute to the increase in wettability values (Ferrari et al., 2012). 
Table 1. Obtained parameters, determination coefficients $\left(R^{2}\right)$ and mean squared deviations (DQM) of mathematical models adjusted to the drying data.

\begin{tabular}{|c|c|c|c|c|c|c|c|c|c|}
\hline \multirow[t]{2}{*}{ Model } & \multirow{2}{*}{$\begin{array}{l}\mathrm{T} \\
\left({ }^{\circ} \mathrm{C}\right)\end{array}$} & \multicolumn{6}{|c|}{ Parameters } & \multirow[t]{2}{*}{$\mathrm{R}^{2}$} & \multirow[t]{2}{*}{ DQM } \\
\hline & & $\mathrm{a}$ & $\mathrm{b}$ & c & $\mathrm{k}$ & $\mathrm{k}_{1}$ & $\mathrm{n}$ & & \\
\hline \multirow[t]{4}{*}{ Diffusion approximation } & 50 & -47.1671 & 0.9851 & - & 0.0120 & - & - & 0.9993 & 0.0138 \\
\hline & 60 & -6.2952 & 0.8908 & - & 0.0187 & - & - & 0.9995 & 0.0114 \\
\hline & 70 & -10.0439 & 0.9318 & - & 0.0225 & - & - & 0.9990 & 0.0160 \\
\hline & 80 & -51.6137 & 0.9857 & - & 0.0340 & - & - & 0.9994 & 0.0127 \\
\hline \multirow[t]{4}{*}{ Two terms } & 50 & 0.5279 & 0.6256 & - & 0.0068 & 0.0068 & - & 0.9947 & 0.0896 \\
\hline & 60 & 0.5364 & 0.5362 & - & 0.0097 & 0.0097 & - & 0.9945 & 0.0383 \\
\hline & 70 & 0.5333 & 0.5331 & - & 0.0124 & 0.0122 & - & 0.9941 & 0.0384 \\
\hline & 80 & 0.5322 & 0.5322 & - & 0.0189 & 0.0189 & - & 0.9946 & 0.0362 \\
\hline \multirow[t]{4}{*}{ Exponential of two terms } & 50 & 0.0001 & - & - & 4.3841 & - & - & 0.9924 & 0.0442 \\
\hline & 60 & 0.0020 & - & - & 5.0702 & - & - & 0.9908 & 0.0497 \\
\hline & 70 & 0.0022 & - & - & 9.7812 & - & - & 0.9910 & 0.0472 \\
\hline & 80 & 0.0022 & - & - & 8.4876 & - & - & 0.9923 & 0.0444 \\
\hline \multirow[t]{4}{*}{ Henderson and Pabis } & 50 & 1.0535 & - & - & 0.0068 & - & - & 0.9947 & 0.0369 \\
\hline & 60 & 1.0726 & - & - & 0.0097 & - & - & 0.9945 & 0.0383 \\
\hline & 70 & 1.0665 & - & - & 0.0122 & - & - & 0.9941 & 0.0384 \\
\hline & 80 & 1.0647 & - & - & 0.0189 & - & - & 0.9949 & 0.0362 \\
\hline \multirow[t]{4}{*}{ Logarithmic } & 50 & 1.1133 & - & -0.0755 & 0.0058 & - & - & 0.9970 & 0.0278 \\
\hline & 60 & 1.1171 & - & -0.0579 & 0.0086 & - & - & 0.9964 & 0.0312 \\
\hline & 70 & 1.1104 & - & -0.0577 & 0.0109 & - & - & 0.9961 & 0.0312 \\
\hline & 80 & 1.0956 & - & -0.0410 & 0.0174 & - & - & 0.9962 & 0.0310 \\
\hline \multirow[t]{4}{*}{ Midilli } & 50 & 0.9711 & -0.0002 & - & 0.0011 & - & 1.3492 & 0.9996 & 0.0096 \\
\hline & 60 & 0.9851 & -0.0001 & - & 0.0016 & - & 1.3619 & 0.9998 & 0.0081 \\
\hline & 70 & 0.9771 & -0.0003 & - & 0.0023 & - & 1.3525 & 0.9994 & 0.0127 \\
\hline & 80 & 0.9806 & -0.0002 & - & 0.0043 & - & 1.3498 & 0.9996 & 0.0103 \\
\hline \multirow[t]{4}{*}{ Newton } & 50 & - & - & - & 0.0063 & - & - & 0.9924 & 0.0442 \\
\hline & 60 & - & - & - & 0.0087 & - & - & 0.9910 & 0.0492 \\
\hline & 70 & - & - & - & 0.0112 & - & - & 0.9912 & 0.0467 \\
\hline & 80 & - & - & - & 0.0175 & - & - & 0.9924 & 0.0439 \\
\hline \multirow[t]{4}{*}{ Page } & 50 & - & - & - & 0.0016 & - & 1.2729 & 0.9992 & 0.0148 \\
\hline & 60 & - & - & - & 0.0020 & - & 1.3274 & 0.9996 & 0.0103 \\
\hline & 70 & - & - & - & 0.0030 & - & 1.3022 & 0.9990 & 0.0155 \\
\hline & 80 & - & - & - & 0.0053 & - & 1.3051 & 0.9994 & 0.0123 \\
\hline \multirow[t]{4}{*}{ Thompson } & 50 & -14.7780 & 1.1623 & - & - & - & - & 0.9922 & 0.0448 \\
\hline & 60 & -31.2822 & 0.5384 & - & - & - & - & 0.9875 & 0.0578 \\
\hline & 70 & -31.2427 & 1.6135 & - & - & - & - & 0.9910 & 0.0471 \\
\hline & 80 & -94.0633 & 1.2892 & - & - & - & - & 0.9920 & 0.0452 \\
\hline \multirow[t]{4}{*}{ Wang and Singh } & 50 & -0.0045 & 0.0001 & - & - & - & - & 0.9966 & 0.0295 \\
\hline & 60 & -0.0060 & 0.0001 & - & - & - & - & 0.9907 & 0.0499 \\
\hline & 70 & -0.0075 & 0.0001 & - & - & - & - & 0.9862 & 0.0585 \\
\hline & 80 & -0.0104 & 0.0001 & - & - & - & - & 0.9661 & 0.0923 \\
\hline
\end{tabular}

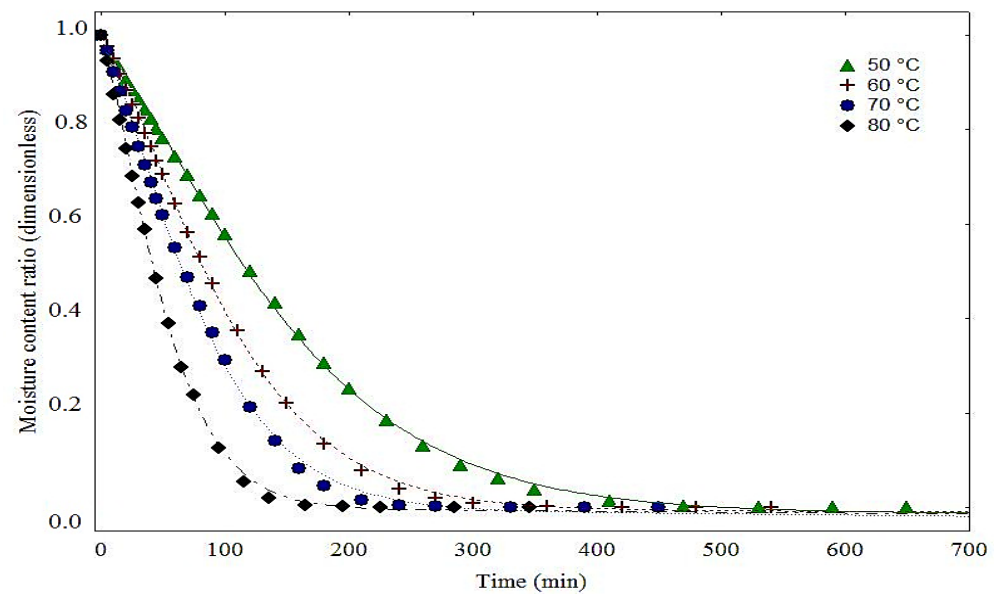

Fig 1. Okra Kinetic drying curves at temperatures of $50,60,70$ and $80^{\circ} \mathrm{C}$ adjusted by the Midilli model. 
Table 2. Effective diffusivity (Def) mean values obtained in Okra drying at 50,60, 70 and $80{ }^{\circ} \mathrm{C}$ and their respective determination coefficients $\left(R^{2}\right)$.

\begin{tabular}{|lll|}
\hline Temperature $\left({ }^{\circ} \mathrm{C}\right)$ & $\mathrm{Def}_{\text {ef }}\left(\times 10^{-11} \mathrm{~m}^{2} \mathrm{~s}^{-1}\right)$ & $\mathrm{R}^{2}$ \\
\hline 50 & 3.13 & 0.9614 \\
\hline 60 & 4.37 & 0.9597 \\
\hline 70 & 5.70 & 0.9627 \\
\hline 80 & 9.00 & 0.9678 \\
\hline
\end{tabular}

Table 3. Mean values of enthalpy $(\Delta \mathrm{H})$, entropy $(\Delta \mathrm{S})$ and Gibbs free energy $(\Delta \mathrm{G})$ in okra drying at $50,60,70$ and $80^{\circ} \mathrm{C}$.

\begin{tabular}{|llll|}
$\begin{array}{l}\text { Temperature } \\
\left({ }^{\circ} \mathrm{C}\right)\end{array}$ & $\begin{array}{l}\Delta H \\
\left(\mathrm{KJ} \mathrm{mol}^{-1}\right)\end{array}$ & $\begin{array}{l}\Delta S \\
\left(\mathrm{KJ} \mathrm{mol}^{-1} \mathrm{~K}^{-1}\right)\end{array}$ & $\begin{array}{l}\Delta \mathrm{G} \\
\left(\mathrm{KJ} \mathrm{mol}^{-1}\right)\end{array}$ \\
\hline 50 & 32.04 & -0.3464 & 143.99 \\
\hline 60 & 31.96 & -0.3467 & 147.46 \\
\hline 70 & 31.88 & -0.3469 & 150.93 \\
\hline 80 & 31.79 & -0.3472 & 154.40 \\
\hline
\end{tabular}

Table 4. Mean values and standard deviations of the pigments and colorimetric parameters evaluated in okra powders obtained by lyophilization and convective drying.

\begin{tabular}{|c|c|c|c|c|c|}
\hline \multirow[t]{2}{*}{ Parameters } & \multirow[t]{2}{*}{ Lyophilization } & \multicolumn{4}{|c|}{$\begin{array}{l}\text { Convective drying } \\
\text { Temperature }\left({ }^{\circ} \mathrm{C}\right)\end{array}$} \\
\hline & & 50 & 60 & 70 & 80 \\
\hline Chlorophyll a ( $\mu \mathrm{g} \mathrm{g}^{-1}$ ) & $1.74 \pm 0.02 \mathrm{a}$ & $0.92 \pm 0.01 b$ & $0.84 \pm 0.01 \mathrm{c}$ & $0.55 \pm 0.01 \mathrm{~d}$ & $0.49 \pm 0.03 d$ \\
\hline Chlorophyll b ( $\left.\mu \mathrm{g} \mathrm{g}^{-1}\right)$ & $0.38 \pm 0.01 \mathrm{a}$ & $0.31 \pm 0.02 b$ & $0.32 \pm 0.04 a b$ & $0.20 \pm 0.01 \mathrm{c}$ & $0.14 \pm 0.03 \mathrm{~d}$ \\
\hline Chlorophyll total $\left(\mu \mathrm{g} \mathrm{g}^{-1}\right)$ & $3.12 \pm 0.03 \mathrm{a}$ & $1.71 \pm 0.01 \mathrm{~b}$ & $1.58 \pm 0.02 \mathrm{c}$ & $1.03 \pm 0.02 \mathrm{~d}$ & $0.89 \pm 0.05 \mathrm{e}$ \\
\hline Carotenoids $\left(\mu \mathrm{g} \mathrm{g}^{-1}\right)$ & $0.99 \pm 0.02 \mathrm{a}$ & $0.49 \pm 0.01 b$ & $0.46 \pm 0.02 \mathrm{bc}$ & $0.44 \pm 0.01 c$ & $0.45 \pm 0.01 \mathrm{bc}$ \\
\hline Luminosity (L*) & $78.18 \pm 0.11$ a & $62.21 \pm 0.34 \mathrm{~d}$ & $64.01 \pm 0.37 c$ & $69.05 \pm 0.34 b$ & $69.12 \pm 0.22 b$ \\
\hline Green intensity $\left(-a^{*}\right)$ & $2.28 \pm 0.14 \mathrm{a}$ & $1.66 \pm 0.14 \mathrm{~b}$ & $1.02 \pm 0.14 \mathrm{c}$ & $0.97 \pm 0.17 \mathrm{c}$ & $0.88 \pm 0.05 c$ \\
\hline Yellow intensity $\left(+b^{*}\right)$ & $22.68 \pm 0.24 \mathrm{a}$ & $17.26 \pm 0.55 \mathrm{c}$ & $18.20 \pm 0.57 \mathrm{c}$ & $20.75 \pm 0.60 \mathrm{~b}$ & $21.46 \pm 0.37 b$ \\
\hline Chroma (C*) & $22.79 \pm 0.26 \mathrm{a}$ & $17.30 \pm 0.56 \mathrm{c}$ & $18.27 \pm 0.58 \mathrm{c}$ & $21.21 \pm 0.61 b$ & $21.48 \pm 0.37 b$ \\
\hline Hue angle $\left({ }^{\circ}\right)$ & $84.29 \pm 0.28 \mathrm{~d}$ & $85.12 \pm 0.34 \mathrm{c}$ & $86.37 \pm 0.29 b$ & $87.32 \pm 0.40 \mathrm{a}$ & $87.67 \pm 0.15 a$ \\
\hline
\end{tabular}

Means followed by the same letter in the lines do not differ statistically by the Tukey test at $5 \%$ probability.

Table 5. Mean values and standard deviations of the physical parameters evaluated in the okra powders obtained by lyophilization and convective drying.

\begin{tabular}{|c|c|c|c|c|c|}
\hline \multirow[t]{3}{*}{ Parameters } & \multirow[t]{3}{*}{ Lyophilization } & \multicolumn{4}{|c|}{ Convective drying } \\
\hline & & \multicolumn{4}{|c|}{ Temperature $\left({ }^{\circ} \mathrm{C}\right)$} \\
\hline & & 50 & 60 & 70 & 80 \\
\hline Hygroscopicity (\%) & $83.33 \pm 0.29 c$ & $87.14 \pm 0.02 \mathrm{a}$ & $84.89 \pm 0.07 b$ & $82.69 \pm 0.14 \mathrm{~d}$ & $82.14 \pm 0.10 \mathrm{e}$ \\
\hline Wetting rate $\left(\mathrm{g} \mathrm{min}^{-1}\right)$ & $3.08 \pm 0.10 \mathrm{~b}$ & $1.89 \pm 0.02 \mathrm{e}$ & $2.21 \pm 0.09 \mathrm{~d}$ & $2.60 \pm 0.13 c$ & $3.37 \pm 0.03 \mathrm{a}$ \\
\hline Solubility (\%) & $63.04 \pm 0.48 \mathrm{a}$ & $32.98 \pm 1.36 \mathrm{~b}$ & $33.63 \pm 3.28 b$ & $34.97 \pm 0.80 \mathrm{~b}$ & $36.95 \pm 0.48 b$ \\
\hline Apparent density $\left(\mathrm{g} \mathrm{cm}^{-3}\right)$ & $0.128 \pm 0.005 \mathrm{e}$ & $0.518 \pm 0.017 \mathrm{a}$ & $0.433 \pm 0.012 b$ & $0.392 \pm 0.008 c$ & $0.370 \pm 0.002 \mathrm{~d}$ \\
\hline Compacted density $\left(\mathrm{g} \mathrm{cm}^{-3}\right)$ & $0.171 \pm 0.007 \mathrm{e}$ & $0.691 \pm 0.019 \mathrm{a}$ & $0.599 \pm 0.02 b$ & $0.522 \pm 0.011 \mathrm{c}$ & $0.466 \pm 0.008 d$ \\
\hline Carr Index (\%) & $25.00 \pm 0.00 \mathrm{a}$ & $25.67 \pm 1.53 \mathrm{a}$ & $25.00 \pm 0.00 \mathrm{a}$ & $25.00 \pm 0.00 \mathrm{a}$ & $20.67 \pm 1.16$ b \\
\hline Hausner Factor & $1.33 \pm 0.00 \mathrm{~b}$ & $1.38 \pm 0.01 \mathrm{a}$ & $1.33 \pm 0.00 \mathrm{~b}$ & $1.33 \pm 0.00 \mathrm{~b}$ & $1.26 \pm 0.02 c$ \\
\hline
\end{tabular}

Means followed by the same letter in the lines do not differ statistically by the Tukey test at $5 \%$ probability.

Table 6. Mathematical models used to estimate okra kinetic drying curves.

\begin{tabular}{|c|c|c|}
\hline Mathematical model designation & Model & Equation \\
\hline Diffusion approximation & $R X=a \cdot \exp (-k \cdot t)+(1-a) \cdot \exp (-k \cdot b \cdot t)$ & (2) \\
\hline Henderson and Pabis & $R X=a \cdot \exp (-k \cdot t)$ & (3) \\
\hline Two terms & $R X=a \cdot \exp (-k \cdot t)+b \cdot \exp \left(-k_{1} \cdot t\right)$ & (4) \\
\hline Exponential of two terms & $R X=a \cdot \exp (-k \cdot t)+(1-t) \cdot \exp (-k \cdot a \cdot t)$ & (5) \\
\hline Logarithmic & $R X=a \cdot \exp (-k t)+c$ & (6) \\
\hline Midilli & $R X=a \cdot \exp \left(-k \cdot t^{n}\right)+b \cdot t$ & (7) \\
\hline Newton & $R X=\exp (-k t)$ & (8) \\
\hline Page & $R X=\exp \left(-k \cdot t^{n}\right)$ & (9) \\
\hline Thompson & $\left.R X=\exp \left(-a-\left(a^{2}+4 \cdot b \cdot t\right)^{0,5}\right) / 2 \cdot b\right)$ & (10) \\
\hline Wang and Singh & $R X=1+(a . t)+\left(b . t^{2}\right)$ & (11) \\
\hline
\end{tabular}



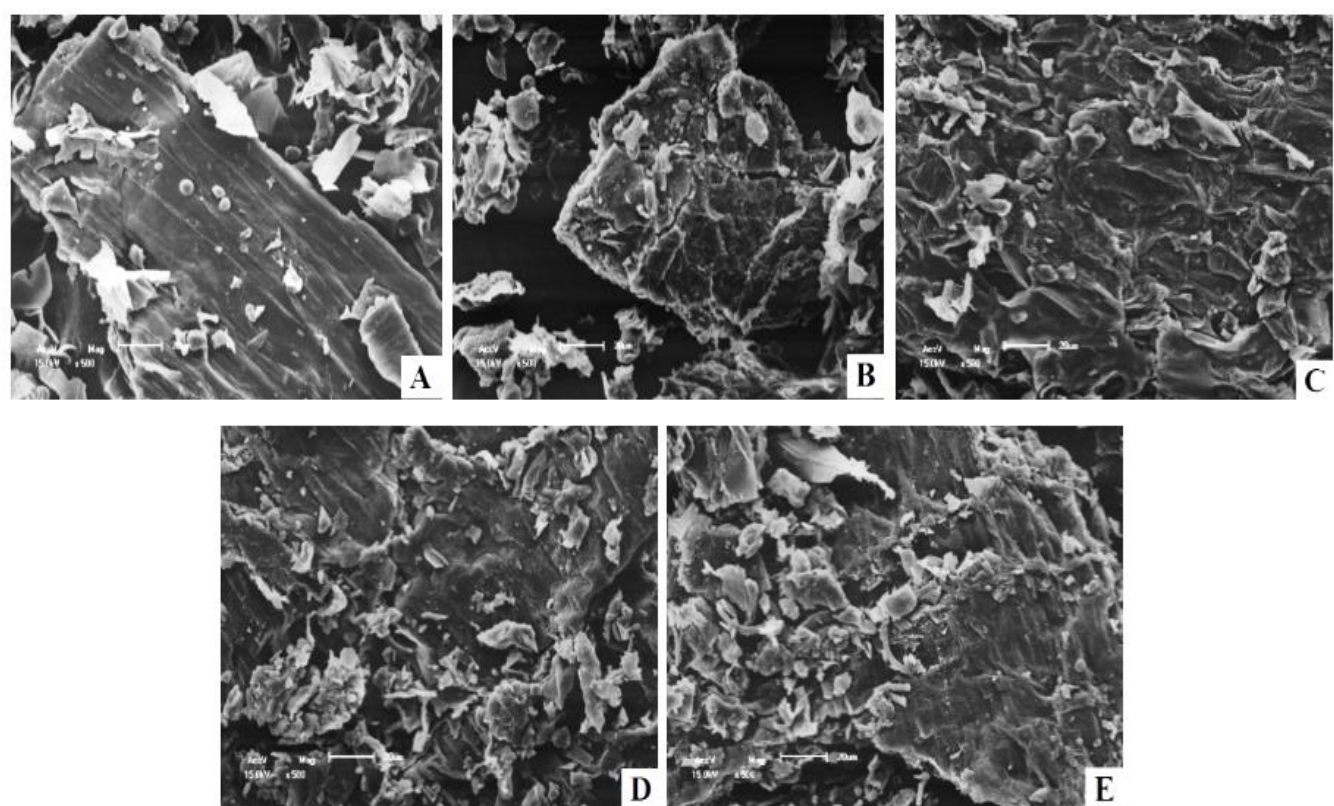

Fig 2. Morphology of powdered okra particles obtained by lyophilization (A) and convective drying at $50{ }^{\circ} \mathrm{C}(\mathrm{B}), 60^{\circ} \mathrm{C}(\mathrm{C}), 70{ }^{\circ} \mathrm{C}(\mathrm{D})$ and $80^{\circ} \mathrm{C}(\mathrm{E})$.

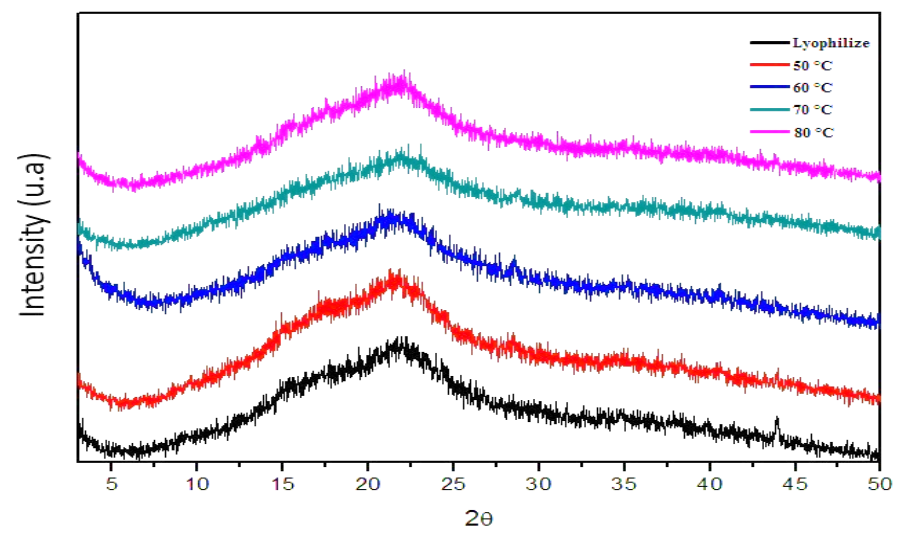

Fig 3. X-ray diffraction spectrum for okra powders.
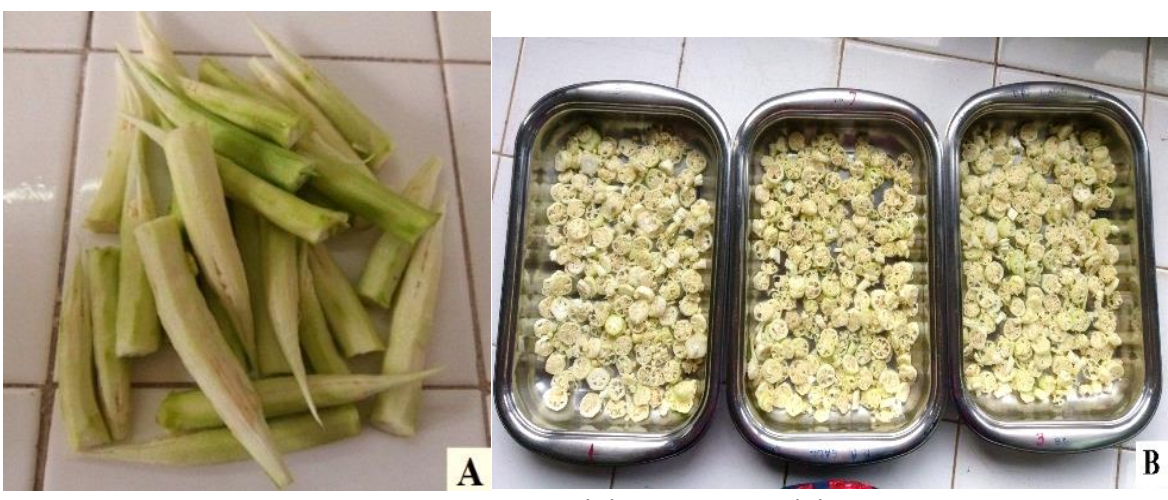

Fig 4. Peeled okras (A); Sliced okras (B). 


\section{$X$-ray diffraction}

The X-ray diffraction spectrum of the powders obtained by both convective drying and lyophilization are shown in Figure 3. X-ray diffraction is a common technique used to confirm the crystalline-amorphous state of products, dried in the powder form. In general, the crystalline material shows a series of pointed peaks, while amorphous products produce a broad background pattern (Caparino et al., 2012).

The X-ray diffraction patterns of the powders, in both drying methods, exhibited amorphous characteristics and showed no crystalline peaks formation. In addition, diffractograms revealed that the amorphous domain of the powders concentrates in $23(2 \theta)$. For the same sample type, if diffraction intensity is reduced, there is a tendency of the curves to become flattered. There is also less difference between minimum and maximum, with the increase of drying temperature. Rapid material drying in the presence of low molecular weight compounds tends to produce dried products in metastable state, due to insufficient time for crystallization (Jayasundera et al., 2011).

Moreover, irreversible changes in the structure of polymeric compounds, cause its molecular structure degration and loss of crystallinity (Anastasiades et al., 2002). Mahdavi et al. (2016) stated that more amorphous characteristics are required for a product to function as a good wall material (carrier) for both hydrosoluble and liposoluble compounds. Therefore, the absence of crystalline peaks in okra powders is a good indicator of a potential application, as a possible wall material or drying adjuvant, depending on the performance of studies that determine its functional properties to ratify this hypothesis.

\section{Materials and methods}

\section{Raw material}

The raw material used in this study was the okra (Abelmoschus esculentus (L.) Moench), from the green subgroup, Santa Cruz variety, which has pointed cylindrical shapes, and average size from 12 to $18 \mathrm{~cm}$, in its green maturation stage.

\section{Drying methods}

First, okras were individually selected, according to their maturation stage and physical integrity. Then, they were washed and sanitized in chlorinated water (50 ppm), for 15 minutes, and finally they were rinsed. In order to be dried, okras were previously peeled (Figure $4 \mathrm{~A}$ ) and crosswise sliced with a standard thickness of $2 \mathrm{~mm}$ (Figure 4B).

\section{Convective drying}

For convective drying, the sliced samples were placed in stainless steel trays (Figure 4B) and submitted to oven drying with forced air circulation at 50, 60, 70 and $80{ }^{\circ} \mathrm{C}$, until reaching hygroscopic equilibrium. After dried, the slices were grounded in a knife mill and sieved in a stainless steel sieve with a mesh of \#32 mesh, for the removal of particles of greater granulometry.

Okra kinetic drying data was obtained in triplicate by weighing the containers with the samples at regular intervals until constant mass. At the end of the drying process, the dry masses were determined and the water contents were calculated. Water content ratio values (Equation 1) were calculated using the experimental data.

$R X=\frac{x-x_{e}}{X_{i}-x_{e}}$

In which: RX - Product water content ratio, dimensionless; $X$ Product water content ratio at a given time, $\%$ dry basis; $\mathrm{Xi}$ Product initial water content, \% dry basis; Xe - Product equilibrium water content, $\%$ dry basis.

The mathematical models of diffusion approximation, Two terms, Exponential of two terms, Henderson and Pabis, Logarithmic, Midilli, Newton, Page, Thompson and Wang and Singh (Table 6) were adjusted to the experimental data of the drying kinetics.

The software Statistica 7.0 was used for mathematical adjustment of the models to the experimental data, through non-linear regression analysis, using the Quasi-Newton estimation method. To evaluate the model adjustment, the coefficient of determination $\left(R^{2}\right)$ and the mean square deviation (DQM) were used (Equation 12).

$\mathrm{DQM}=\sqrt{\frac{\sum(\text { RXpred-RXexp }) 2}{n}}$

In which: DQM - Mean square deviation; RXpred - Water content ratio predicted by the model, dimensionless; RXexp Experimental non-dimensional water content ratio; $\mathrm{n}$ Number of observations.

Samples effective diffusivity for the drying temperatures of 50 to $80{ }^{\circ} \mathrm{C}$ were calculated, according to the liquid diffusion theory; in which equation is the analytical solution for the second law of Fick, comparing the geometric form of the product with approximation of a flat plate and with approximation of five terms $(n=5)$, (Equation 13).

$R X=\left(\frac{8}{\pi^{2}}\right) \sum_{n=0}^{\infty}\left(\frac{1}{(2 n+1)^{2}}\right) \exp \left(-(2 n+1)^{2} \pi^{2} \frac{D_{e f}}{L^{2}} t\right)$

In which: RX - Water content ratio, dimensionless; $\mathrm{n}$ - Number of equation terms; Def - effective diffusivity $\left(m^{2} s-1\right)$; L thickness (m); $\mathrm{t}$ - time (s).

Arrhenius equation (Equation 14) was adjusted to the data, in order to obtain the activation energy, to evaluate the influence of the drying temperature on the effective diffusivity (Def).

$D_{\text {ef }}=D_{\text {efo }} \exp \frac{E_{a}}{R T}$

In which: Def0 - pre-exponential factor $\left(\mathrm{m}^{2} \mathrm{~s}^{-1}\right)$; Ea - activation energy $\left(\mathrm{kJ} \mathrm{mol}{ }^{-1}\right) ; \mathrm{R}$ - universal gas constant, $0.8314 \mathrm{~kJ} \mathrm{~mol}^{-1} \mathrm{~K}^{-1}$; $\mathrm{T}$ - absolute temperature (K).

\section{Thermodynamic properties}

The thermodynamic properties of the drying process enthalpy, entropy, and Gibbs free energy, were determined according to Equations 15, 16 and 17, respectively (Corrêa et al., 2012).

$\Delta \mathrm{H}=\mathrm{E}_{\mathrm{a}}-\mathrm{R} \mathrm{T}$

$\Delta S=R\left(\ln A_{0}-\ln \frac{K_{B}}{h_{p}}-\ln T\right)$ 
$\Delta \mathrm{G}=\Delta \mathrm{H}-\mathrm{T} \Delta \mathrm{S}$

In which: $\Delta \mathrm{H}$ - enthalpy variation $\left(\mathrm{kJ} \mathrm{mol}^{-1}\right)$; Ea - activation energy ( $\left.\mathrm{kJ} \mathrm{mol}{ }^{-1}\right) ; \mathrm{R}$ - universal gas constant, $0.8314 \mathrm{~kJ} \mathrm{~mol}^{-1} \mathrm{~K}^{-1}$; $\mathrm{T}$ - absolute temperature $(\mathrm{K}) ; \Delta \mathrm{S}$-entropy variation $\left(\mathrm{kJ} \mathrm{mol}^{-1} \mathrm{~K}^{-}\right.$ $\left.{ }^{1}\right)$; Kb - Boltzmann constant, $1.38 \times 10^{-26} \mathrm{~kJ} \mathrm{~K}^{-1}$; hp - Planck's constant, $6.626 \times 10^{-37} \mathrm{~kJ} \mathrm{~s} ; \Delta \mathrm{G}$ - Gibbs free energy variation (kJ $\left.\mathrm{mol}^{-1}\right)$.

\section{Lyophilization}

Sliced okras were frozen at $-18{ }^{\circ} \mathrm{C}$, for 48 hours, and taken to a Liobras brand lyophilizer machine, model L101, for a period of 72 hours. The raw material was grounded in a knife mill and sieved in \#32 mesh stainless steel sieves in order to obtain powder samples.

\section{Powders characterization}

\section{Pigment analysis}

The chlorophyll $a, b$ as well as the powders total carotenoids, obtained in both convective drying and lyophilization, were quantified after extraction using $80 \%$ acetone and calcium carbonate, with spectrophotometer absorbance readings at 470, 646 and $663 \mathrm{~nm}$, according to Lichtenthaler (1987). Results were expressed in $\mu \mathrm{g} / \mathrm{g}$, on a dry basis.

\section{Colorimetric analysis}

The instrumental colorimetric parameters were determined by direct reading using a Hunter Lab Mini Scan XE Plus portable spectrophotometer, model $4500 \mathrm{~L}$, in the Cielab color system. The parameters were: $L^{*}$ - luminosity; $a^{*}$ - transition from green $\left(-a^{*}\right)$ to red $\left(+a^{*}\right)$; and $b^{*}$ - transition from blue $\left(-b^{*}\right)$ to yellow $\left(+b^{*}\right)$; and from the values of $a^{*}$ and $b^{*}$, the chroma values were determined $\left(C^{*}\right)$ (Equation 18 ) and hue angle (h) (Equation 19):

$C^{*}=\sqrt{(a *)^{2}+\left(b^{*}\right)^{2}}$

$\mathrm{h}=\tan ^{-1}\left(\mathrm{~b}^{*} / \mathrm{a}^{*}\right)$

\section{Physical characterization}

\section{Hygroscopicity}

Hygroscopicity was determined according to Cai and Corke (2000), and the results were expressed in grams of adsorbed water per $100 \mathrm{~g}$ of sample mass.

\section{Solubility}

Solubility was determined according to the method described by Schoch (1964). In addition, a centrifuge at $3200 \mathrm{rpm}$ was used for 15 minutes, with its supernatant removed and brought to the oven at $105^{\circ} \mathrm{C}$ for $24 \mathrm{~h}$ for the determination of soluble mass.

\section{Wettability}

The wettability was determined by the method of Schubert (1993), expressed by the mass (g)/time required for the disappearance of the sample ratio ( $\mathrm{min})$.

\section{Apparent and compacted density}

The apparent density (pap) was determined by the weight of the sample in a $10 \mathrm{~mL}$ beaker filled with the powder and the mass/volume ratio was calculated. The compacted density was determined in the same test tube containing the powder, subjecting it to 50 times beating on the bench, at an approximate height of $2.5 \mathrm{~cm}$, and the compacted ratio mass/volume was then calculated (Tonon et al., 2009).

\section{Carr index and Hausner's factor}

Carr index $(\mathrm{Cl})$ and Hausner's factor $(\mathrm{FH})$ were determined according to Wells (1988) methodology, based on both apparent density ( $\rho a p)$ and compacted density ( $\rho c)$ data, according to Equations 20 and 21:

$\mathrm{IC}=\frac{\rho_{\mathrm{c}-\rho_{\mathrm{ap}}}}{\rho_{\mathrm{ap}}} 100$

$\mathrm{FH}=\frac{\rho_{\mathrm{c}}}{\rho_{\mathrm{ap}}}$

\section{Particle morphology}

Particle's morphological analysis was determined by scanning electron microscopy (SEM), on a Shimadzu SSX-550 Superscan equipment, operating at $15 \mathrm{kV}$. In order to obtain the images by MEV, the samples were plated with a gold alloy for 360 seconds, with $10 \mathrm{~mA}$ current in Shimadzu IC-50 metallizer, under high vacuum conditions, to provide a reflecting surface for the electron beams. Then, the samples were visualized under the microscope and their morphological structures were photographed in 500X magnifications.

\section{$X$-ray diffraction}

The scanning method was used for X-ra y diffraction analysis, which consists of $\mathrm{X}$-rays incidence on powder samples, compacted on a support, using Shimadzu XRD-6000 apparatus with CuKa radiation, voltage of $40 \mathrm{KV}, 30 \mathrm{~mA}$ current, step size of $0.0202 \theta$ and time per step of $1.00 \mathrm{~s}$, with a scanning speed of $2^{\circ}(2 \theta) / \mathrm{min}$, with a $2 \theta$ angle traveled from 4 to $50^{\circ}$. The values of the crystalline planes with the distance of the wavelength $\lambda$ of $X$ - radiation were determined according to the Bragg equation (22), which consists of the recorded intensity of diffracted rays versus the double diffraction angle $(2 \theta)$.

$\mathrm{n} \lambda=2 . \mathrm{d}($ h.k.l) $\sin \theta$

In which: $n$ - reflection order; $\lambda$ - electromagnetic radiation wavelength used; $\mathrm{d}$ (hkl) - distance between planes; $\theta$ - Bragg angle of the crystalline plane.

\section{Statistical analysis}

The results of the physical analyses were submitted to analysis of variance and their means were compared by the Tukey test, at $5 \%$ probability. The Assistant version 7.7 beta software was used (Silva and Azevedo, 2016).

\section{Conclusion}

The mathematical model of drying proposed by Midilli was the one that better adjusted for the representation of the drying kinetics of sliced okra. The effective diffusion coefficient increased as the drying air temperature also increased, and presented an activation energy for the liquid diffusion, during the drying process of $32.46 \mathrm{~kJ}$ mol-1. Enthalpy and entropy values decreased with the increase of drying temperature, and Gibbs free energy was directly proportional to temperature. 
The lyophilized powder presented high luminosity, with greater retention of pigments and greater solubility. All powders presented poor fluidity and intermediate cohesiveness. They were presented as morphologically irregular, showing asymmetric particles with amorphous characteristics. From the present study it was possible to evaluate the best drying method that should be applied for the drying of okra taking into account its costs, its quality and the final product application, meeting the needs of consumers.

\section{References}

Alves CCO, Resende JV, Cruvinel RSR, Prado MET (2008) Stability of the microstructure and carotenoids contents of the freeze-dried pequi (Caryocar brasiliense Camb.) pulp in the powdered form. Rev Food Sci T. 28: 830-839.

Anastasiades S, Thanou D, Loulis A, Stapatoris, TD (2002) Rheological and physical characterization of pregelatinized maize starches. J Food Eng. 52: 57-66.

Araujo WD, Goneli ALD, Corrêa PC, Hartmann Filho CP, Martins EAS (2017) Mathematical modeling of the drying of peanut fruits in thin layer. Rev Ciênc Agron. 48: 448-457.

Bohn T, Walczyk T (2004) Determination of chlorophyll in plant samples by liquid chromatography using zincphthalocyanine as an internal standard. J Chromat. 1024: 123-128.

Cai YZ, Corke H (2000) Production and properties of spray-dried Amaranthus betacyanin pigments. J Food Scienci. 65: 1248-1252.

Canuto GAB, Xavier AAO, Neves LC, Benassi MT (2010) Physical and chemical characterization of fruit pulps from amazonia and their correlation to free radical scavenger activity. Rev Bras Frutic. 32: 1196-1205.

Caparino OA, Tang J, Nindo $\mathrm{Cl}$, Sablani SS, Powers JR, Fellman JK (2012) Effect of drying methods on the physical properties and microstructures of mango (Philippine 'Carabao' var.) powder. J Food Eng. 111: 135-148.

Carvalho JMG, Bueno SGS, Oliveira DEC, Resende O (2018) Mathematical modeling and determination of thermodynamic properties of coffee (Coffea arabica L.) during the drying process. GI Sci T. 11: 136-149.

Corrêa PC, Resende O, Martinazzo AP, Goneli ALD, Botelho FM (2007) Mathematical modelling for describing the drying process of the edible bean (Phaseolus vulgaris L.) in thin layers. Eng Agríc. 27: 501-510.

Corrêa PC, Oliveira GHH, Botelho FM, Goneli ALD, Carvalho FM (2010) Mathematical modeling and determination of the thermodynamic properties of coffee (Coffea arabica L.) during the drying process. Ceres Magazine. 57: 595-601.

Corrêa PC, Oliveira GHH, Santos ES (2012) Thermodynamic properties of agricultural products processes. In: ARANA, I. Physical properties of foods: novel measurement techniques and applications. 1: 131-141.

Corrêa Filho LC, Andrade ET, Martinazzo AP, Andrea EM, Sousa FA, Figueira VG (2015) Drying kinetics, shrinkage and analysis of liquid diffusion of figs (Ficus carica L.). RBEAA. 19: 797-802.

Derlan JM, Silva FS, Porto AG, Leite ALMP, Pastro DC (2013) Analysis of drying kinetics of Cambuci pepper at different temperatures and ways of processing. Encícl Biosf. 9: 97-107.

Doymaz I, Sahin M (2016) Effect of temperature and pretreatment on drying and rehydration characteristics of broccoli slices. J Food Meas Charact. 10: 364-373.

Elmas F, Varhan E, Koç M (2019) Drying characteristics of jujube (Zizyphus jujuba) slices in a hot air dryer and physicochemical properties of jujube powder. J Food Meas Charact. 13: 70-86.

Fan S, Zhang Y, Sun Q, Yu L, Zheng B, Wu X, Yang B, Li Y (2014) Extract of okra lowers blood glucose and serum lipids in high-fat diet-induced obese C57BL/6 mice. J Nutr Biochem. 25: 702-709.

Fernandes RVB, Queiroz F, Botrel DA, Rocha VV, Souza VR, Lima CF (2014) Study of the albumin addition and drying temperature on the characteristics of tomato pulp powder. S Ciênc Agrárias. 35: 1267-1278.

Ferrari CC, Germer SPM, Fernanda IDA, Alvim ID, Aguirre FZ, Vissotto JM (2012) Influence of carrier agents on the physicochemical properties of blackberry powder produced by spray drying. Int J Food Sci Tecnol. 47: 1237-1245.

Gea Niro Research Laboratory (2003) Wettab Método Niro, GEA Niro analytical methods. Soeborg, Dinamarca: GEA Niro.

Geidobler R, Winter G (2013) Controlled ice nucleation in the field of freeze-drying: fundamentals and technology review. Eur J Pharm biopharm. 85: 214222.

Goneli ALD, Correa PC, Oliveira GHH, Botelho FM (2010) Water desorption and thermodynamic properties of okra seeds. ASABE. 53: 191-197.

Goneli ALD, Vieira MC, Vilhasanti HCB, Gonçalves AA (2014) Mathematical modeling and effective diffusion of Schinus terebinthifolius leaves during drying. Pesq Agrop Trop. 44: 56-64.

Goyal A, Sharma V, Sihag MK, Tomar SK, Arora S, Sabikhi LA, Singh K (2015) Development and physico-chemical characterization of microencapsulated flaxseed oil powder: a functional ingredient for omega-3 fortification. Powder Technol. 286: 527-537.

Guiné RPF, Henriques F, Barroca MJ (2014) Influence of drying treatments on the physical and chemical properties of cucumber. J Food Meas Charact. 8: 195206. 
Gupta K, Alam MS (2014) Mass and color kinetics of foamed and non-foamed grape concentrate during the convection drying process: A comparative study. Eng Research Magazine Tec. 6: 48-67.

Harnkarnsujarit N, Charoenrein S, Roos YH (2012) Porosity and water activity effects on stability of crystalline 8 -carotene in freeze-dried solids. J Food Sci. 77: 313-320.

Jaya S, Das H (2004) Effect of maltodextrin, glycerol monostearate and tricalcium phosphate on vacuum dried mango powders properties. J Food Eng. 63: 125134.

Jayasundera M, Adhikari B, Adhikari R, Aldred P (2011) The effect of protein types and low molecular weight surfactants on spray drying of sugar-rich foods. Food Hydrocoll. 25: 459-469.

Kpodo FM, Agbenorhevi JK, Alba K, Bingham RJ, Oduro IN, Morris GA, Kontogiorgos V (2017) Pectin isolation and characterization from six okra genotypes. Food Hydrocoll. 72: 323-330.

Kuck LS, Noreña CPZ (2016) Microencapsulation of grape (Vitis labrusca var. Bordo) skin phenolic extract using gum arabic, polydextrose, and partially hydrolyzed guar gum as encapsulating agents. Food Chem. 194: 569-576.

Lannes SCS, Medeiros ML (2003) Processing of cupuaçu chocolate by spray dryer. Braz J pharm sci. 39, 115123.

Leite ALMP, Silva FS, Porto AG, Santos DP (2015) Volumetric contraction and drying kinetics of banana slices of Musa sapientum variety. Agriculture research Trop. 45: 155-162.

Lichtenthaler HK (1987) Chlorophylls and carotenoids: Pigments of photosynthetic biomembranes. Methods Enzymol. 148: 350-382.

Madamba PS (2003) Thin layer drying models for osmotically pré-dried young coconut. Dry technol. 21: 9.

Mahdavi SA, Jafari SM, Assadpoor E, Dehnad D (2016) Microencapsulation optimization of natural anthocyanins with maltodextrin, gum Arabic and gelatin. Int J Biol Macromol. 85: 379-385.

Martins JJA, Marques JI, Santos DC, Rocha APT (2014) Mathematical modeling of the drying of husks Mulungu. Biosci J. 30: 1652-1660.

Martins EAS, Lage EZ, Goneli ALD, Hartmann Filho CP, Lopes JG (2015) Drying kinetics of Serjania marginata Casar leaves (Serjania marginata Casar). RBEAA. 19: 238-244.

Melo JCS, Pereira ED, Oliveira KP, Costa CHC, Figueirêdo RMF (2015) Study smell pepper drying kinetics in different temperature. RVADS. 10: 9-14.

Mendonça K, Jacomino AP, Melhem TX, Kluge RA, (2003) Concentration of Ethylene and Exposure Time for De-
Greening of 'Siciliano' Lemons. Braz J food technol. 6: 179-183.

Moreira R, Chenlo F, Torres MD, Valle N (2008) Thermodynamic analysis of experimental sorption isotherms of loquat and quince fruits. J Food Eng. 88: 514-521.

Moreira IS, Silva WP, Castro DS, Silva LMM, Gomes JP, Silva CMDPS (2018) Production of kiwi snack slice with different thickness: Drying kinetics, sensory and physicochemical analysis. Aust J Crop Sci. 12: 778-787.

Moscon ES, Martin S, Spehar CR, Devilla IA, Rodolfo Junior F (2017) Quinoa grain drying kinetics (Chenopodium quinoa W.). Eng Agric. 25: 318-328.

Mota WF, Finger FL, Cecon PR, Silva DJH, Corrêa PC, Firme LP, Mizobutsi GP (2010) Preservation and postharvest quality of okra under different temperatures and forms of storage. Hortic Bras. 28: 12-18.

Nascimento IB, Ferreira LE, Medeiros JF, Aroucha EMM, Sousa CMG, Silva NKC, Izidio NSC (2013) Postharvest quality of okra submitted to different layers of saline water. ACSA. 9: 88-93.

Nascimento APS, Lima AKS, Cavalcanti CF, Gusmão RP (2015) Drying kinetics of mesquite pods (Prosopis juliflora SW). RVADS. 10: 115-119.

Oliveira GHH, Aragão DMS, Oliveira APLR, Silva MG, Gusmão ACA (2015). Modeling and thermodynamic properties in the drying of strawberries. Braz $\mathrm{J}$ food technol. 18: 314-321.

Oliveira DEC, Resende O, Costa LM (2016) Effects of drying on the color of baru fruits (Dipteryx alata Vogel). Agroamb Online. 10: 364-370.

Perez LG, Oliveira FMN, Andrade JS, Moreira Filho M (2013) Kinetic drying of cupuaçu pulp (Theobroma grandiflorum) pre-dehydrated by immersionimpregnation. Rev Ciênc Agron. 44: 102-106.

Reis DS, Figueiredo Neto A, Ferraz AV, Freitas ST (2017) Production and conservation stability of dehydrated acerola flour at different temperatures. Braz $\mathrm{J}$ food technol. 20: 1-7.

Ren CAF, Perussello JP, Kerry ZZ, Brijesh KT (2017) Effect of agronomic practices and drying techniques on nutritional and quality parameters of onions (Allium cepa L.). Dry technol. 36: 435-447.

Resende O, Oliveira DEC, Costa LM, Ferreira Júnior WN (2018) Study of the drying of mesocarp of baru (Dipteryx alata Vogel) fruits. Eng Agríc. 38: 10-31.

Roy A, Shrivastava SL, Mandal SM (2014) Functional properties of Okra Abelmoschus esculentus $\mathrm{L}$. (Moench): traditional claims and scientific evidences. Plant Sci Today. 3: 121-130.

Santhalakshmy S, Bosco SJD, Francis S, Sabeena M (2015) Effect of inlet temperature on physicochemical properties of spray-dried jamun fruit juice powder. Powder Technol. 274: 37-43. 
Santos FS, Figueirêdo RMF, Queiroz AJM, Santos DC (2017) Drying kinetics and physical and chemical characterization of white-fleshed 'pitaya' peels. RBEAA. 21: 872-877.

Santos D C, Leite DDF, Lisbôa JF, Ferreira JPL, Santos FS, Lima TLB, Figueiredo RMF, Costa TN (2019) Modelling and thermodynamic properties of the drying of acuri slices. Braz J food technol. 22: 1-12.

Schoch TJ (1964) Fatty substances in starch. In: WHISTLER R. L. Methods in carbohydrates. Academic Press.

Schubert H (1993) Food particle technology. Part I: properties of particles and particles food systems. J Food Eng. 6: 1-32.

Silva FAS, Azevedo CAV (2016) The Assistat Software Version 7.7 and its use in the analysis of experimental dat a. Afr J Agric Res. 11: 3733-3740.

Silva HRP, Cuco RP, Porciuncula BDA, Silva C (2017) Evaluation of thermodynamic and kinetic parameters of carrots subjected to convective drying. E-xacta. 10: 73-80.
Sogi DS, Siddiq M, Dolan KD (2015) Total phenolics, carotenoids and antioxidant properties of Tommy Atkin mango cubes as affected by drying techniques. LWT - Food Sci and Techn. 62: 564-568.

Souza DS, Souza JDRP, Coutinho JP, Ferrão SPB, Souza TS, Silva AAL (2012) Preparation of instant flour from the pulp of breadfruit (Artocarpus altilis). Ciênc Rural. 42: 1123-1129.

Tonon RV, Brabet C, Pallet D, Brat P, Hubinger MD (2009) Physicochemical and morphological characterization of açai (Euterpe oleraceae Mart.) powder produced with different carrier agents. Inter J Food Sci T. 44: 1950-1958.

Wells JI (1988) Pharmaceutical preformulation: the physicochemical properties of drug substances. New York: Ellis Horwood Limited.

Zogzas NP, Maroulis ZB, Marinos-Kouris D (1996) Moisture diffusivity data compilation in foodstuffs. Dry technol. 14: 2225- 2253. 